\title{
O recurso ao diário em $A$ Noite da Espera, de Milton Hatoum: o desenho de um conflito pessoal e de um conflito histórico-político
}

\author{
The use of diary in Milton Hatoum's A Noite da Espera: \\ the drawing of a personal conflict and a historical-political conflict \\ El recurso a lo diario en A Noite da Espera, de Milton Hatoum: \\ el diseño de un conflicto personal y un conflicto histórico-político \\ Alexandre Luiz Ribeiro da Fonseca Júnior () \\ Universidade Federal de Minas Gerais, Belo Horizonte, MG, Brasil.
} $\diamond$

\begin{abstract}
RESUMO
O presente artigo visa à análise do recente livro de Milton Hatoum, A Noite da Espera, publicado em 2017 e pertencente à trilogia $O$ Lugar mais Sombrio. Tal análise procura identificar no romance, escrito em forma de diário ficcional, a potencialidade da escrita de si como espaço de autoconhecimento, de autorreflexão e de resistência diante da dupla crise vivida pelo narrador: uma crise de ordem familiar e outra de ordem histórico-política, representada pela ditadura civil-militar brasileira. Ademais, enxergam-se os vestígios e as ruínas como consequentes desse processo crítico, proporcionando entender o diário como a escrita mais pertinente nesse espaço-tempo caótico.
\end{abstract}

Palavras-chave: Diário ficcional. Memória traumática. Crise e ruínas. Ditadura civil-militar.

\section{ABSTRACT}

This paper aims to present an analysis on Milton Hatoum's recent work, A Noite da Espera, published in 2017, and part of O Lugar mais Sombrio trilogy. The analysis of this fictional diary novel is engaged in the identification of the potentiality of self-representation as a means to selfknowledge, self-reflection and resistance against the double crisis experienced by the narrator, that is, a familiar one, and a historical-political one due to brazilian civil-military dictatorship. In addition, the trace elements and ruins are considered consequences of this critical process, what stands for the understanding of the diary as a more appropriate genre for this chaotic context.

Keywords: Fictional diary. Traumatic memory. Crisis and ruins. Civil-military dictatorship.

\section{RESUMEN}

Este artículo tiene como objetivo analizar el reciente libro de Milton Hatoum, A Noite da Espera, publicado en 2017 y perteneciente a la trilogía O Lugar mais Sombrio. Este análisis busca identificar en la novela, escrita en forma de un diario ficticio, la potencialidad de la auto escritura como un espacio de autoconocimiento, autorreflexión y resistencia a la doble crisis experimentada por el narrador: una crisis familiar y una crisis histórico-política, representada por la dictadura civil-militar brasileña. Además, las huellas y las ruinas se ven como una consecuencia de este proceso crítico, que proporciona la comprensión del diario como la escritura más pertinente en este espacio-tiempo caótico.

Palabras clave: Diario ficticio. Memoria traumática. Crisis y ruinas. Dictadura civil-militar.

"Minha língua é a arma com a qual defendo a dignidade do homem."

(ROSA, 2019) 


\section{Introdução}

Reconfigurar o passado no presente, reatualizar o vivido pela sombra dos vestígios deixados, reunir fragmentos e ruínas: eis o trabalho da memória. Memória esta, que, em contexto de crise, revela-se calcada em traumas por vezes insuperáveis. Diante do horror, ou se cala, ou se paralisa, ou se recalca o vivenciado. No entanto, as palavras podem surgir para dar lugar ao testemunho, ao relato e a uma nova "ética da representação", de acordo com Seligmann-Silva (2003), com o intuito de representar o irrepresentável da barbárie. Nesse sentido, a produção literária tem muito a nos mostrar, tanto pela força de expressão quanto pela temática trabalhada e proposta.

$\mathrm{Na}$ série literária brasileira, tendo como base a produção contemporânea, encontram-se duas grandes vertentes de narrativas: aquelas cuja temática se fundamenta e se ambienta no espaço urbano, amalgamando os discursos do marginal e do excluído, e as narrativas de memória, representativas de uma discussão a respeito do passado histórico, posto em revisão e em reinterpretação, em consonância com a busca pela identidade e pelo autoconhecimento do indivíduo em um espaço em crise, onde as múltiplas configurações identitárias colocam em xeque a ideia de nação e de nacional. Nesse sentido, em um ensaio em que busca fornecer um panorama da literatura brasileira contemporânea, a professora doutora Maria Zilda Ferreira Cury refere-se à produção sedimentada na recuperação de um passado como formadas por:

[...] escritas com ênfase nos mecanismos da memória, tingidas por interpretações da história do país, pondo em relevo estratégias ficcionais de recuperação da memória coletiva e histórica, mas também da pessoal, em que mesclam o local e o nacional, o particular e o universal, não como memórias essencialistas ou lineares (CURY, 2007, p. 11).

Ou seja, são narrativas que mesclam a memória coletiva à memória individual, tendo em vista $\mathrm{o}$ reconhecimento de um passado, por vezes, traumático, no presente da enunciação. E o passado traumático a ser tratado neste artigo é a cruel ditadura civil-militar brasileira, regime vigente no País entre 1964 e 1985.

\section{A produção literária brasileira e a ditadura civil-militar}

O romance a ser abordado, A Noite da Espera, escrito por Milton Hatoum, publicado em 2017 e pertencente à trilogia O Lugar mais Sombrio, revela, em suas páginas, o terrível momento atravessado pelo País a partir do golpe militar de 1964. Inserindo-se na vertente de literatura de memória ${ }^{1}$, nesse romance de formação, o autor deixa patente o seu compromisso com a realidade histórica representada pela ditadura civil-militar brasileira. Dessa forma, o escritor vem se aliar à produção ficcional brasileira que, desde pelo menos a redemocratização, tem se debruçado sobre o período ditatorial. Basta lembrar títulos tais como: Amores Exilados (1997), de Godofredo de Oliveira Neto, Não Falei (2004), de Beatriz Bracher, História natural da Ditadura (2006), de Teixeira Coelho, Soledad no Recife (2009), de Urariano Mota, Azul Corvo (2010), de Adriana Lisboa, O punho e a renda (2010), de Edgard Telles Ribeiro, K-Relato de uma busca (2011), de Bernardo Kucinski, Mar Azul, de Paloma Vidal (2012) e Vidas provisórias (2013), de Edney Silvestre. Além desses, existem produções anteriores: Um romance de geração (1980), de Sérgio Sant'Anna, Em liberdade (1981), de Silviano Santiago, e Tropical sol da liberdade (1988), de Ana Maria Machado.

É interessante notar que, a partir de 2014, ano do cinquentenário do golpe de 1964 , a produção literária a respeito desse período se intensificou, trazendo títulos como: Qualquer maneira de amar: um romance à sombra da ditadura (2014), de Marcus Veras; Damas da noite (2014), de Edgard de Telles Ribeiro; Tempos extremos (2014), de Miriam Leitão; A resistência (2015), de Julián Fuks; Palavras cruzadas (2015), de Guiomar de Grammont; Nuvem negra (2016), de Eliana Cardoso; De mim já nem se lembra (2016), de Luiz Rufatto; Quarenta dias (2014) e Outros cantos (2016), de Maria Valéria Rezende; Cabo de guerra (2016), de Ivone Benedetti; Os visitantes (2016), de Bernardo Kucinski; Lua de vinil, de Osmar Pilagallo (2016); Rio-Paris-Rio (2016), de Luciana Hidalgo, Noite dentro da noite: uma autobiografia (2017), de Joca Reiners Terron e o romance de Milton Hatoum, aqui discutido e analisado. O expressivo número de produções literárias relacionadas ao regime autoritário, a partir de 2014, explica-se, segundo o sociólogo e professor Fernado Perlatto, por:

[...] uma espécie de boom na publicação de romances que elegeram a ditadura como contexto e cenário das narrativas ficcionais. Este boom pode estar associado ao interesse editorial no sentido de se aproveitar as rememorações em torno do cinquentenário do golpe de 1964 para a publicação de livros relacionados a esta temática, ou pode ser vinculado a um movimento geracional de escritores que não vivenciaram diretamente os anos repressivos e que vêm procurando, via ficção, lidar com esse passado autoritário (PERLATTO, 2017, p. 729).

\footnotetext{
1 Tendo em vista os seus romances antecedentes, profundamente marcados pela reconfiguração de um passado a partir de uma voz da margem, cuja busca de um tempo perdido pela memória se expressa na procura de uma possível identidade, que se mostra híbrida e fragmentada, Milton Hatoum se encontra aliado à vertente do discurso de memórias na literatura brasileira contemporânea.
} 
Desse modo, depois dessa longa lista de produções literárias, percebe-se que o romance de formação $A$ Noite da Espera insere-se na literatura brasileira contemporânea como um daqueles que, por meio da narrativa de memória, apresenta o passado conflituoso da ditadura civil-militar brasileira. Pode-se, nesse sentido, entender a literatura como meio propício para resistência, empenhando-se em deixar vivo na memória o passado sangrento de um período autoritário e repressivo, produtor e reprodutor de uma violência de caráter institucional. Em alusão a Antonio Candido (2009), trata-se realmente de uma "literatura empenhada" ", empenhada em dar voz aos perseguidos, aos torturados e aos massacrados por um golpe que rompeu com a democracia e tolheu a liberdade individual e coletiva. Como pretende Ricardo Piglia (2001), em seu reconhecido ensaio Uma Proposta para o Novo Milênio ${ }^{3}$, a literatura contemporânea deve criar mecanismos para o agenciamento de um novo espaço discursivo, que dê conta das vozes recalcadas e marginalizadas, a fim de que se expressem e relatem sua dor, sua experiência extrema. É preciso, assim, sair do centro, deixar que a linguagem fale também em sua borda, ir ao outro e darlhe voz, deslocando-se. Assim, recuperar ficcionalmente o tenebroso regime militar é dar voz aos silenciados e censurados e, contemporaneamente, é fazer com que essa voz seja ouvida e nunca esquecida, pois esquecer o passado tem consequências sérias. Dessa forma, a literatura, cujo empenho se manifesta no trabalho com a palavra, segundo Roberto Vecchi e Regina Dalcastagnè (2014, p. 12), pode dar luz "aos restos, aos despojos, às ruínas e às destruições do passado, proporcionando uma monumentalidade alternativa", permitindo, assim, "reimaginar e narrar, inclusive no labirinto tormentoso de um passado que continua fugindo e não se deixa integralmente, ainda, apreender" (VECCHI; DALCASTAGNÈ, 2014, p. 12).

\section{A sinuosa noite da espera}

Tendo em vista o que foi até agora delineado, chegase ao ponto fulcral deste artigo: o romance $A$ Noite da Espera. Partindo da consideração anterior a respeito do caráter iluminador da literatura diante das ruínas, dos restos, das lacunas e dos despojos, salienta-se que se está lidando com uma narrativa fundamentada em um diário ficcional, gênero propriamente fragmentado

\footnotetext{
2 Referência à segunda seção da introdução do livro Formação da Literatura Brasileira: Momentos Decisivos, de Antonio Candido. O crítico apresenta como característica do sistema literário brasileiro o empenho político e de afirmação como forma de consciência histórica e de nacionalismo crítico.

3 Ensaio em que se apresenta mais uma proposta para o novo milênio para a literatura, em diálogo com as cinco propostas de Ítalo Calvino, que propusera seis, embora apresentasse apenas cinco. Dessa forma, Piglia elabora a sexta, identificando o deslocamento discursivo e enunciativo como a proposta em falta.
}

e repleto dos vestígios do tempo. Philippe Lejeune, em um ensaio intitulado Um diário todo seu, aponta para essa característica do diário, ao afirmar, dentre outras características, que "O diário é um vestígio: quase sempre uma escritura manuscrita, pela própria pessoa, com tudo que a grafia tem de individualizante. [...] O diário é uma série de vestígios" (LEJEUNE, 2014, p. 301).

Em A Noite da Espera, tais vestígios vão se desenvolver de uma maneira um pouco inusitada. $\mathrm{Na}$ verdade, existem dois diários, um subjacente ao outro. Martim, o protagonista, abre o livro com a seguinte frase: "Inverno e silêncio. Nenhuma carta do Brasil" (HATOUM, 2017, p.11). Tal construção indica que o enredo não se passa em solo brasileiro, o que se confirma com a primeira entrada propriamente diarística logo após: "Paris, dezembro, 1977" (HATOUM, 2017, p. 11). Sabe-se que, no presente da enunciação, o narrador está exilado em Paris e mantém um diário, cuja marcação temporal se dá entre 1977 e 1979 . No entanto, motivado possivelmente por uma busca de si em um momento de profunda crise, ele reúne vestígios do passado vivido em Brasília entre 1968 e 1972, momento em que também mantém um diário. Logo, o diário em Paris serve para o narrador refletir suas ações vividas em Brasília a partir de um distanciamento crítico, temporal e espacial.

Lendo a narrativa, percebe-se que Martim vive um duplo trauma: um de ordem familiar e outro de ordem político-histórica. Aos 16 anos, vivia em São Paulo com os pais até que sua mãe resolve se separar e viver com um amante, um artista e pintor de quadros. O pai, revoltado, muda-se com o filho para Brasília logo no início de 1968. Tal fato abala profundamente a vida do adolescente, pois espera incessantemente rever e reencontrar sua mãe, o que não ocorre, causando em si excessiva angústia e frustração. Essa situação, logo de início, cria uma atmosfera profundamente insólita e produz perturbações diversas no íntimo do adolescente. Evidencia-se o surgimento, desde então, de fraturas e de cicatrizes que acompanharão o protagonista por toda a narrativa, colaborando, portanto, para uma profunda e amarga crise identitária, insuflada no período de exílio em Paris, no qual, devido à natureza ambivalente do exilarse, a desterritorialização de si mesmo coloca o narrador diante do caos de uma individualidade fragmentada e traumatizada, momento no qual nasce o diário com toda a subjetividade que lhe é intrínseca.

É interessante notar, a partir do momento de separação dos pais, as divergências existentes entre o espírito materno e o espírito paterno, diametralmente opostos. Os trechos a seguir ilustram e demonstram a extrema perturbação ocasionada e as singularidades inerentes a cada um dos personagens, denotando a figura racional, autoritária e centrada do pai e a figura mais fantasiosa, 
livre e aventureira da mãe, cujo protagonismo inverte o discurso patriarcal, colocando-se contra ele:

Um artista, um pintor. Sabia apenas isso do homem que seduziu minha mãe. Em 22 de dezembro de 1967, ela saiu de casa e foi viver com o artista. Essa decisão inesperada, talvez intempestiva, me perturbou (HATOUM, 2017, p. 19).

Logo em seguida, em uma conversa entre Rodolfo, o pai de Martim, e Dácio, o tio, revela-se o desprezo ou o desdém do primeiro pela produção artística, fato significativo diante da separação, tendo em vista que Lina, mãe de Martim, separara-se para viver com um artista. Ademais, demonstra o a supervalorização da técnica e das atividades científicas em detrimento das expressões artísticas, vistas com maus olhos sob o regime ditatorial, haja visto o poder de crítica e de contestação da arte. Nesse sentido, a arte poderia representar um verdadeiro perigo ao status quo da ditadura e a todo tipo de abuso do poder, sendo, por essa razão, vítima de censura:

Na última conversa do tio Dácio à rua Tutoia, Rodolfo interrompeu uma conversa sobre poetas e fotógrafos, e disse que o progresso e a civilização eram um triunfo da engenharia (HATOUM, 2017, p. 22).

O cenário sufocante amplia-se quando é anunciada a Martim a sua partida para Brasília e o rompimento do elo físico com a mãe. Nesse instante, ocorre a primeira grande perda, a primeira grande fratura, o primeiro grande corte: simbolicamente, corta-se "o cordão umbilical" e daí se irrompe um indivíduo a esmo, sem mãe. O conforto uterino é desfeito por um golpe em posição paralela ao golpe dado à democracia. Desfaz-se o lugar de origem, dele se afasta, nasce o primeiro exílio, perde-se a infância na adolescência, pois da mãe se distancia. Como atesta a psicanalista Kelly-Lainé (2004, p.7), ao associar o fenômeno do exílio à perda de um espaço-tempo precedente e de origem, “ 'a infância perdida' combina com a perda da terra, da língua materna, dos odores, dos sonidos e dos sabores da 'mãe', ali é onde 'a infância perdida' transforma-se em real mais que simbólica." $\mathrm{Ou}$, como bem esclarece Kristeva (1994, p. 12-13), ao discorrer sobre a perda e o desafio do estrangeiro:

No ponto mais longínquo em que sua memória remonta, ela está deliciosamente magoada: incompreendido por uma mãe amada e, contudo, distraída, discreta e preocupada, o exilado é estranho à própria mãe. [...] O estrangeiro, portanto, é aquele que perdeu a mãe.

Dessa forma, é diante dessa perda profundamente dolorosa e desnorteadora, motivo de exílio e de fraturas expostas, que Martim se coloca enquanto um adolescente ao mudar-se com o pai para Brasília, impossibilitado de escolher o seu caminho, e, mais tarde, já um jovem universitário, ao exilar-se em Paris. Os excertos a seguir evidenciam a situação de desespero e de profunda angústia vivida pelo narrador ao saber da separação entre si e sua mãe, condicionando-lhe a uma longa noite da espera:

Eu é que fiquei desnorteado quando Dácio afirmou à queima-roupa: 'Você vai morar com Rodolfo em Brasília, Martim'. O olhar de Lina devolvia minha apreensão. 'Brasília?', repeti. 'Com meu pai em Brasília?' 'Ele conseguiu um bom emprego numa repartição da capital. Quer viver longe da tua mãe. É mais fácil esquecer' (HATOUM, 2017, p. 23).

'Teu pai decidiu morar em Brasília', ela disse, segurando e apertando minhas mãos. 'Eu e o meu companheiro... nós nos apaixonamos, Martim. Você vai entender. Escreve para o endereço do teu tio. Brasília é uma cidade diferente, mas você vai gostar de lá'. Quando ela ia me ver? 'Daqui a poucos meses, filho'. Escutei uma voz meiga e um choro sufocado, depois senti o corpo da minha mãe: o abraço mais demorado e triste da minha vida de dezesseis anos (HATOUM, 2017, p. 25).

Perde-se a mãe e se vai com o pai para Brasília. Percebe-se, a partir de então, que, em contrapartida à figura materna, o pai é alguém profundamente ligado à carreira e venera o regime militar, encarnando em si o esboço da autoridade e da opressão. Tal característica faz com que Martim e ele se distanciem, pois o jovem ingressa na UnB, faz amigos que são ativistas do movimento estudantil e que criam a revista Tribo, na qual eram tecidas críticas ao regime vigente, fato que culmina posteriormente na perseguição pelos militares. O trecho seguinte revela a postura de Martim diante do pai, representado como símbolo da repressão - mesmo velada -, da perseguição, do ódio e até mesmo de um certo grau de loucura, encarnando em si um representante da violência simbólica ${ }^{4}$.

Rodolfo $[\ldots]$ recortou fotografias do rosto $[\ldots]$ do marechal Costa e Silva; coleciona rostos militares e civis (o ministro da Justiça que redigiu o AI-5, magistrados e políticos bajuladores) [...]. A mesa da sala ficou coberta de imagens de heróis do meu pai, e o chão repleto de rostos de papel, cortados em tiras finas, como serpentinas de uma festa macabra. Tive uma vaga consciência de que Rodolfo estava enlouquecendo, percebia sintomas de loucura nos gestos e atitudes dele, e me perguntava quem, ou o quê, ele odiava (HATOUM, 2017, p. 55).

\footnotetext{
4 Cf. BOURDIEU, 2002, p. 47. Sobre o conceito de "violência simbólica", desenvolvido pelo sociólogo e pensador francês Pierre Bourdieu, segundo o qual tal violência se manifestaria por intermédio da adesão que o dominado não pode deixar de conceder ao dominante, proporcionado uma relação de dominação vista como natural.
} 
Além disso, em um instante de extrema inquietação, em que o protagonista confunde a própria sombra com a sombra do pai, adensa-se em uma atmosfera de sufoco, surgindo, por fim, a imagem de Rodolfo como legítimo defensor do governo ditatorial, intitulando-o como "nosso governo patriótico":

Percebi uma sombra no chão, como se alguém me vigiasse. Virei o corpo para trás, esperando ver meu pai enquadrado no vão escuro da porta, feito um fantasma. Era minha própria sombra. [...] Rodolfo falou comigo: 'Ontem mais de mil estudantes foram à assembleia do Parlamento Latino-Americano. Eles e os políticos da oposição dormiram no Congresso Nacional. Querem desmoralizar nosso governo patriótico' (HATOUM, 2017, p. 48).

Diante do exposto, fica evidente, portanto, que, em comunhão ao trauma familiar vivido por Martim em seu interior, existe o trauma sofrido pelo País referente ao período histórico e político em contexto de regime de exceção: trauma na democracia e na liberdade de expressão. Nesse sentido, mescla-se o individual ao social, ou histórico, perfazendo um movimento intenso e crítico, sintetizado ficcionalmente pela oposição entre o pai e a mãe. Sobre essa oposição entre o pai, autoritário e opressor, e a mãe, alegoria da liberdade perdida, revela-nos, Martim, em mais um trecho bem significativo de seu diário:

A voz da minha mãe sumia e voltava. Entendi que ela não poderia viajar tão cedo para Brasília. Não falei mais, talvez por estar emocionado, e também frustrado. A voz, tão longe, foi abafada por sons estridentes. Larguei o telefone e senti a presença de meu pai. Sério, braços cruzados, me encarava com um olhar que não decifrei (HATOUM, 2017, p. 33).

É salutar perceber a intensidade provocada por esse trecho, cujo movimento da voz materna acaba por levar ao abafamento dela diante da presença do pai. Sons estridentes e um olhar indecifrável, quiçá censurador, impedem a liberdade em um regime de exceção: a violência, embora disfarçada, logo simbólica, assoma ao texto e faz compreender a mescla entre conflitos íntimos e conflitos político-históricos atravessados e vividos pelo narrador ao longo de todo diário, configurando, assim, a base de sua composição e escrita. Longe da mãe e da democracia, Martim coloca-se a escrever para suportar o peso da realidade e para armar-se durante a longa noite da espera, na vã ilusão do advento materno:

A crença de que a qualquer momento ela chegaria dificultou meu sono, eu emergia assustado de um cochilo e via o rosto da minha mãe num lugar sombrio do quarto, ou deitado na cama, o corpo quieto e frio como de uma morta; essas visões, entre o milagre e o sobrenatural, me assustavam e me deixaram prostrado na longa noite da espera (HATOUM, 2017, p.98).

\subsection{O diário e o exílio: um lugar sem mãe}

Como foi delineado, a escrita em um contexto subjetivo revela-se entremeada das aflições e das angústias vividas pelo indivíduo. Sob uma atmosfera de repressão e de fraturas identitárias, no exílio, à distância da mãe e da pátria, o protagonista do romance analisado está submerso em um lugar ambivalente e sem pontos fixos. Incorre-lhe a ideia de escrever e datilografar seus escritos em forma de diário, ancorado em suas memórias e na memória dos outros, já que, segundo Martim, “(...) sem a memória dos outros eu não poderia escrever" (HATOUM, 2017, p. 71)

Havendo tecido um breve resumo da obra na seção precedente, cabe agora retornar ao início do livro, rever a questão do exílio, apresentar alguns trechos e tentar responder à seguinte questão: por que a escrita de um diário? Em primeiro lugar, partir-se-á das reflexões teóricas de Edward Said a respeito do fenômeno representado pelo exílio. Sabe-se que a situação de um exilado, principalmente em um regime de exceção, representa a mais profunda crise identitária, prefigurando um indivíduo rompido, flutuante, que precisa agenciar e negociar com o outro, pois é um estrangeiro, um "estranho", conforme a perspectiva freudiana ${ }^{5}$. Acaba, assim, tornando-se um estrangeiro para si mesmo, pois não pertence a lugar algum, mesmo estando paradoxalmente em dois: o lugar de origem e o lugar atual. Quer voltar para sua terra natal, a mesma que o baniu. No lugar atual, não se sente pertencido. É, assim, um ser fraturado, rompido, fragmentado. Ou seja, surgem e se irrompem mais ruínas, mais lacunas e mais vestígios. Said, no ensaio Reflexões sobre o exílio, aponta, mais de uma vez, para essa situação. Segundo o autor, o exílio é:

[...] uma fratura incurável entre um ser humano e um lugar natal, entre o eu e seu verdadeiro lar: sua tristeza essencial jamais pode ser superada. E, embora seja verdade que a literatura e a história contêm episódios heroicos, românticos, gloriosos e até triunfais da vida de um exilado, eles não são mais do que esforços para superar a dor mutiladora da separação. As realizações do exílio são permanentemente minadas pela perda de algo deixado para trás para sempre (SAID, 2003, p. 46).

Sendo assim, logo no início da obra, Martim enuncia:

\footnotetext{
Cf. FREUD, 1976, p.273-318. Sobre o conceito de "inquietante estranheza".
} 
Um expatriado pode esquecer seu país em vários momentos do dia e da noite, ou até por um longo período. Mas o pensamento de um exilado quase nunca abandona seu lugar de origem. E não apenas por sentir saudade, mas antes por saber que o caminho tortuoso e penoso do exílio é, às vezes, um caminho sem volta (HATOUM, 2017, p. 15).

Ora, em perfeito diálogo com o pensamento de Said, percebe-se que o narrador vive, pelo exílio, uma fratura praticamente incurável e, nesse espaço-tempo, anseia por buscar se encontrar. Encarna, de fato, como evidenciado pelo trecho acima, o pathós do exílio, pois se situa distante da solidez e distante da sua terra, havendo consciência de que voltar é algo impensável, tendo em vista as dificuldades inerentes ao deslocamento do exilado. Vale lembrar ainda que, ao sair do Brasil, Martim já atravessa uma dupla crise, na qual a mãe alegoriza a democracia perdida. Há um profundo abalo na identidade já fragmentada. Sem mãe, sem liberdade, sem pátria, sem mátria, o que resta? Resta a solidão do exílio, resta, segundo Said (2003), a necessidade urgente de o exilado reconstituir sua vida rompida e construir uma identidade a partir de refrações e de descontinuidades. Resta, enfim, o abandono e o desespero, o arruinado deslocado e órfão. Novamente a figura do distanciamento materno surge como amálgama do paraíso perdido. Martim, também como um jovem tradutor, obteve pelos versos de Rimbaud uma possível revelação do íntimo de seu ser. Ao traduzir Les Déserts de l'Amour, talvez se encontre representado por aquele indivíduo sem mãe e sem país, como de fato é. Em uma carta na qual a mãe comenta sobre a tradução feita pelo filho - estupefata e desconfiada diante da escolha do texto tão simbólico e, ao mesmo tempo, tão cruel -, presencia-se claramente a desesperança e o desamparo sofridos por Martim em situação de exílio físico e psíquico:

Li os poemas que você publicou na Tribo, filho. E também tua tradução de "Os desertos do amor". Tento entender esse texto, que me deixou angustiada. Por que você o escolheu para traduzir? "Um jovem sem mãe e sem país... na noite surda e na fuga da felicidade..." É um texto tão bonito quanto estranho. Você se sente assim? Triste, abandonado, desesperado? (HATOUM, 2017, p. 165).

As fraturas expostas crescem e arruínam a vida do jovem em meio à fragmentação interior, ao luto e à melancolia. Há desencontros abismais entre o presente e o passado, lançando-se a um futuro dolorosamente incerto. O caráter suspenso do imigrante, do exilado, supõe uma falta de identificação sólida consigo mesmo e com o local no qual habita provisoriamente. Os laços com a terra natal foram brutalmente cortados, mas desse corte profundo surgem fantasmas diversos, atormentadores do momento em que se enuncia. Nesse sentido, assinala Kristeva (1994, p. 17) ao referir-se à melancolia do estrangeiro:

A dura indiferença talvez seja somente a face confessável da nostalgia. Conhecemos o estrangeiro que chora eternamente o seu país perdido. Enamorado melancólico de um espaço perdido, na verdade, ele não se consola é por ter abandonado uma época de sua vida. O paraíso perdido é uma miragem do passado que jamais poderá ser reencontrada.

Logo, das ruínas do passado ilumina-se o presente, mais conflituoso e instável. No entanto, essa iluminação não se passa de uma ilusão fantasmagórica, pois o reencontro com o tempo pretérito é praticamente impossível. Essa ilusão encontra espaço central na experiência do exílio e se adensa na linguagem, nas palavras e na escrita, conforme relata Martim: "Talvez seja isso o exílio: uma longa insônia em que fantasmas reaparecem com a língua materna, adquirem vida na linguagem, sobrevivem nas palavras..." (HATOUM, 2017, p. 210). Associa-se a esse estado descontínuo e angustiante o fato de o exílio provocar fenômenos de criatividade e de tristeza, conforme a perspectiva de Said (2003), abrindo terreno para o "luto cultural", dor manifesta pela perda de algo deixado para trás na terra de origem e que implica em reconfigurações e em adaptações várias. Suportar o insuportável é difícil e penoso como Martim revela novamente: "Nem tudo é suportável quando se está longe... A memória ofusca a beleza desta cidade." (HATOUM, 2017, p. 13). Em meio a perdas e a ruínas, cujas marcas se metamorfoseiam em cicatrizes da história, e envolto ao sufoco angustiante proporcionado pelo exílio, Martim vai em busca de seu tempo perdido e de seus vestígios. Tendo arquivado sua memória em "cadernos, fotografias, cadernetas, folhas soltas, guardanapos com frases rabiscadas, cartas e diários de amigos" (HATOUM, 2017, p.17), ele começa a datilografar os seus manuscritos: "anotações intermitentes, escritas aos solavancos: palavras ébrias num tempo salteado" (HATOUM, 2017, p. 17).

Eis que aí surge o diário: o espaço descontínuo dos vestígios. Em um momento de profunda crise e abalo, o diário surge como motor de resistência, de pensamento e até mesmo de sobrevivência. De acordo com Lejeune (2014, p.303), “o diário é um espaço onde o 'eu' escapa momentaneamente à pressão social, se refugia protegido em uma bolha onde pode abrir sem risco, antes de voltar, mais leve, ao mundo real." $\mathrm{O}$ autor ainda questiona: "Como 'aguentar' quando a vida submete-nos a uma prova terrível? Como transformar o 'foro íntimo' em campo de defesa onde recuperamos as energias e buscamos forças? O diário pode trazer coragem e

\footnotetext{
6 Cf. VIEIRA, 2016, p. 48- 62 .
} 
apoio" (LEJEUNE, 2014, p.305). Ora, além de poder conservar a memória, fixar o tempo e esconjurar a morte, o diário se apresenta na tentativa de promover o autoconhecimento, as deliberações, os pensamentos, as reflexões e a liberdade do ato de escrita. Tais pontos se convergem na narrativa de Milton Hatoum, na qual o protagonista, como se percebe, mostra-se profundamente abalado por um momento de dupla crise. Dessa forma, ele pode, a partir do diário, resistir, lutar, sobreviver, ser livre e conhecer-se, mesmo fraturado e fragmentado. Ademais, para Martim, a escrita, como forma de criatividade do exílio, também se ancora na possibilidade de se reconfigurar e de refazer, mesmo que por fragmentos e ruínas, o seu 'eu' interior. Desfalcado, esfacelado e semlugar, o narrador utiliza do diário para dar vazão à ilusão da miragem do passado, encontrando, pelas palavras, a mãe, a pátria e a liberdade perdidas. Como em um jogo de quebra-cabeça, ele reúne os fragmentos aos solavancos para compor e recompor sua história em tempo salteado. Tenta, assim, a busca por si e pela mãe, na ansiosa espera em uma noite que parece não ter fim no lugar mais sombrio, no recôndito mais profundo de seu ser. Lamenta o jovem Martim, confirmando as palavras anteriores: "Tentava recompor o rosto de minha mãe; me lembrava dele aos pedaços, como peças de um quebra-cabeça em lugares e tempos diferentes. Como juntar essas peças e armar o quebra-cabeça? Esse jogo desafiava minha memória [...]" (HATOUM, 2017, p. 90). Utiliza, assim, de sua escrita íntima e de suas anotações, para, no espelho das palavras, enxergar a imagem materna e com ela conversar: "Minhas anotações são um modo de conversar com ela, de pensar nela. Coloquei dentro do caderno a folha de papel dobrada e amassada, com apenas duas palavras: 'Querida mãe", (HATOUM, 2017, p. 39). A escrita subjetiva do diário de Martim revela uma falta e um vazio enormes; sem a mãe, errante e solitário, encontra no ato de escrever a possível superação dessas lacunas, ancorado no apoio ofertado gratuitamente pelo diário. Um diário de si mesmo; um diário que nasce da falta, da melancolia e das fraturas. Dessa forma, o narrador se abre para o exercício de uma escrita libertadora, pacificadora e propiciadora de uma possível reorganização dos fatos vividos, garantindo, embora por meio da ilusão, a confiança em uma estabilidade imersa no caos e o esconjuramento da morte, já que se subtende que, diferentemente do corpo real, o corpo simbólico da escrita do diário sobreviverá e poderá servir de testemunho ao porvir.

\subsection{O diário e o testemunho histórico-político}

Tendo em vista o exposto, evidenciou-se a escrita diarística como espaço de uma subjetividade fraturada e, de fato, exilada. O diário de Martim se abre também para o testemunho do horror consequente do período ditatorial brasileiro em meio a toda violência institucionalizada e simbólica, propiciadoras de um profundo recalcamento. Nesse sentido, utiliza-se da escrita para evitar o processo de recalcamento e de silenciamento advindos da censura, denunciando a crueldade do regime de exceção e testemunhando os fatos vividos, no intuito de conservá-los na memória e destiná-los à prova do futuro. Como manifestação premente desse testemunho, mesmo que por meio de recursos próprios da literatura e da ficção, basta considerar que as referências ao golpe civil-militar de 1964 no livro são inúmeras: o recrudescimento do regime militar com a promulgação do AI-5 (13 de dezembro de 1968), a morte do general e presidente Costa e Silva (1969), a era do governo do general Médici (1969-1974), a morte dos jovens estudantes no Rio de Janeiro pelos militares durante a chamada "Sexta-Feira Sangrenta" (21 de junho de 1968), a Passeata dos Cem Mil (junho de 1968). Os trechos seguintes evidenciam tais acontecimentos: "Lázaro acrescentou que no dia 21 a polícia matou três estudantes durante uma manifestação no Rio. 'Anteontem, teve uma passeata de cem mil pessoas"” (HATOUM, 2017, p. 48). E:

Só no dia 14 entendi o motivo do júbilo paterno: o Ato Institucional número 5. Nesta última semana de dezembro, Rodolfo empilhou revistas e jornais na mesa da sala e recortou fotografias do rosto [...] do marechal Costa e Silva (HATOUM, 2017, p.48).

Logo no início do livro, em alusão a uma conversa entre Martim e seu aluno francês em 1977 e em Paris, sugere-se o clima político atormentador, grave e terrível vivido pelo país pós-golpe de 1964:

Hoje, em Neulliy-sur-Seine, meu aluno francês me ofereceu um café e quis conversar um pouco sobre o Brasil. O bate-papo, de início besta, aos poucos rondou um assunto mais cabeludo, que logo ficou grave; para ir da gravidade ao terror político bastaram duas xícaras de café e uns biscoitos (HATOUM, 2017, p. 11).

Aliadas a essas referências históricas, surge a ficção que dá luz ao ambiente acadêmico e universitário e seu posicionamento diante do contexto político, ao aguerrido movimento estudantil, à repressão contra as universidades, à violência e à tortura, seguidas do exílio. $\mathrm{O}$ excerto seguinte permite visualizar a consciência política dos grupos de manifestantes e o ativismo estudantil referido:

Sexta: as aulas da tarde foram canceladas, a maioria dos alunos do Centro de Ensino Médio tinha ido à assembleia no campus. Durante o almoço no bandejão, os universitários falavam de comícios-relâmpagos e protestos em vários lugares: rua da Igrejinha, praça Vinte e Um de Abril, calçada da Casa Thomas 
Jefferson... Um alto-falante no barracão da Federação de Estudantes transmitia uma música estranha, parecia marcha militar. Dinah distribuía panfletos e me chamou. Ombros nus, lábios vermelhos, o olhar inteligente no meu rosto. Quando ela me deu um panfleto, consegui dizer que ia ver um filme no Cultura. "Filme? Ontem a polícia matou um estudante no Rio. Não é hora de ir pro cinema. Mais tarde o Geólogo vai fazer um comício perto da Escola Parque. O Nortista e o Fabius vão pra lá" (HATOUM, 2017, p.39-40).

Diante da atual conjuntura sócio-política, em que discursos de ódio e de intolerância estão se tornando atos cruéis e em que a memória de um tempo tenebroso como a ditadura civil-militar ora é relativizada, ora negada, ora até mesmo exaltada no apreço por um torturador, a leitura de $A$ Noite da Espera e de outras obras que tematizem a ditadura se faz mais do que necessária. É, novamente, a literatura empenhada como forma de luta e de resistência frente ao autoritarismo e ao fim da liberdade de expressão.

\section{Considerações finais}

É momento, pois, de pensar a literatura a partir da margem, cuja voz enunciativa e discursiva delineia-se fora do centro, fora dos limites do discurso dominante histórico-político. Pelas páginas desse diário ficcional, constata-se a voz de um exilado, Martim, aquele que, por anos, esteve silenciado e censurado. Rompida e arruinada, a vida desse indivíduo é colocada à prova de resistência, simbolizando, a partir da escrita, a sua desejada imortalidade e o seu colocar-se à disposição do futuro. Situar-se fora do centro para garantir o direito ao grito, o direito de reagir frente ao silenciamento e ao apagamento perpetrados pelo autoritarismo. É preciso que a ditadura civil-militar seja desvelada a fim de que se encarem os seus efeitos tenebrosos. O professor Jaime Ginzburg, em um ensaio sobre o narrador na literatura brasileira contemporânea, alerta para esse fato:

[...] a ditadura militar e suas heranças consistem ainda em desafios para a crítica literária brasileira. Há muito a ser compreendido em termos das perspectivas adotadas pelos escritores para lidar com o impacto social do processo ditatorial, tendo em vista as práticas de política do esquecimento, a hegemonia do discurso militarista e as recentes contribuições de pesquisas históricas. (GINZBURG, 2012, p. 216)

Ler a obra de Milton Hatoum, especialmente $A$ Noite da Espera, requer que se reconheça esse desafio de lidar com o período ditatorial, porém garante a possibilidade de escutar a voz descentrada de Martim e, junto a ele, fazer de seu testemunho uma forma de evitar o esquecimento de tantos traumas, de tantas torturas, de tanta violência
- institucionalizada e simbólica - e de tantas crises. A literatura empenha-se em resistir frente ao discurso de apagamento da memória e encena, a partir das ruínas, a vivacidade do enfrentamento e da luta.

Ademais, ao refletir sobre o tema proposto para a IX Semana da Letras e para o VIII Seminário de Pesquisa Discente do POSLIT-UFMG (SPLIT) ${ }^{7}$, percebe-se que, diante da política contemporânea, os estudantes têm o papel de agir e de resistir frente aos discursos de ódio, de preconceito e de intolerância. Sobretudo precisam se posicionar diante da retirada de direitos fundamentais, a começar pela defesa da educação pública de qualidade para todos e do desenvolvimento da pesquisa e da ciência. É crucial, sim, desenvolver senso crítico e dele se utilizar para a construção do conhecimento. Portanto, são necessários a união e o espelhamento na atuação aguerrida do movimento estudantil durante o regime militar. Martim e seus amigos, pelas páginas desse romance de formação em forma de diário ficcional, vêm mostrar e ensinar como a militância estudantil pôde atuar sob um regime de exceção. Mais do que isso: vêm testemunhar o quão cruel foi o período militar para que dele não se esqueça e para que se possa zelar de fato pela democracia acima de tudo. Eis o poder da literatura, eis a forma de resistência por meio das palavras. Que essa longa noite da espera faça de todos atentos e vigilantes, permitindo que ele não se sobreponha aos direitos inalienáveis de cada cidadão! Um apelo à consciência!

\section{Referências}

BLANCHOT, Maurice. O recurso ao "diário". In: O espaço literário. Rio de Janeiro: Rocco, 1987. p. 19-20.

BOURDIEU, Pierre. A dominação masculina. Trad. Maria Helena Kühner. Rio de Janeiro: Bertrand Brasil, 2002.

CANDIDO, Antonio. Formação da Literatura Brasileira: Momentos Decisivos. Rio de Janeiro/São Paulo: Ouro sobre Azul/FAPESP, 2009.

CURY, Maria Zilda Ferreira. Novas geografias discursivas. Letras de Hoje, Porto Alegre, v. 42, n. 4, p. 7-1, dez. 2007.

FREUD, Sigmund. O estranho. Rio de Janeiro: Imago, 1976, p. 273-318. (Edição standard brasileira das obras psicológicas completas de Sigmund Freud, v. XVII).

GINZBURG, Jaime. O narrador na literatura brasileira contemporânea. Tintas. Quaderni di letterature iberiche e iberoamericane, [s.l.], v. 2, p. 199-221, 2012.

\footnotetext{
A temática proposta para o evento em questão centrou-se nas perspectivas, propostas e desafios para os estudantes de Letras perante a política contemporânea. Ocorreu entre os dias 22 a 26 de outubro de 2018 na Faculdade de Letras da UFMG. O presente artigo é fruto de uma comunicação apresentada durante o supracitado evento.
} 
HATOUM, Milton. A Noite da Espera. São Paulo: Companhia das Letras, 2017.

KELLY-LAINÉ, K. Preface in three voices. In: SZEKACSWEISZ, J.; WARD, I. Lost childhood and the language of exile. London: Imago MLPC and The Freud Museum, 2004.

KRISTEVA, Julia. Estrangeiros para nós mesmos. Trad. Maria Carlota Carvalho Gomes. Rio de Janeiro: Rocco, 1994.

LEJEUNE, Philippe. Um diário todo seu. In: NORONHA, Jovita Maria Gerheim (org.). O pacto autobiográfico: de Rousseau à Internet. Trad. Jovita Maria Gerheim Noronha e Maria Inês Coimbra Guedes. Belo Horizonte: Editora UFMG, 2014.

PERLATTO, Fernando. História, literatura e a ditadura brasileira: historiografia e ficções no contexto do cinquentenário do golpe de 1964. Estudos Históricos, Rio de Janeiro, v. 30, n. 62, p. 721-740, set./dez. 2017. https://doi. org/10.1590/s2178-14942017000300011

PIGLIA, Ricardo. Una propuesta para el nuevo milenio. Margens, Belo Horizonte, n. 2, p. 1-3, out. 2001.

ROSA, João Guimarães. Diálogo com Guimarães Rosa. In: Guimarães Rosa: ficção completa v. 1. Rio de Janeiro: Nova Aguilar, 2009, 2 v.

SAID, Edward. Reflexões sobre o exílio e outros ensaios. Trad. Pedro Maia Soares. São Paulo: Companhia das Letras, 2003.

SELIGMANN-SILVA, Márcio. Introdução. In: SAID, Edward. História, memória, literatura: o testemunho na era das catástrofes. Campinas: Editora UNICAMP, 2003. p. 7-44.

VECCHI, Roberto; DALCASTAGNÈ, Regina. Apresentação. Estudos de Literatura Brasileira Contemporânea. Literatura e Ditadura, Brasília, n. 43, p. 11-12, jan./jun. 2014. https://doi. org/10.1590/S2316-40182014000100001

VIEIRA, Nelson H. Fora do Brasil-globalização e deslocamento na literatura brasileira contemporânea: migração transnacional e luto cultural. In: CHIARELLI, Stefania; OLIVEIRA NETO, Godofredo. Falando com estranhos - o estrangeiro e a literatura brasileira. Rio de Janeiro: 7letras, 2016

Recebido em: 5/11/2019.

Aprovado em: 12/12/2019.

Publicado em: 7/1/2020.

Autor:

Alexandre Luiz Ribeiro da Fonseca Júnior

Mestrando, Universidade Federal de Minas Gerais, Belo Horizonte, MG, Brasil.

Orcid: https://orcid.org/0000-0002-7043-2285

E-mail: alexandre.r.fonseca@hotmail.com

Endereço: Universidade Federal de Minas Gerais

Av. Antonio Carlos, 6627 - Pampulha

31270-901, Belo Horizonte, MG, Brasil 